\title{
Convalescent plasma therapy for COVID-19: a review of old therapy against new disease
}

\section{Utshav Chapagain*, Gajendra Prasad Rauniar, Kumud Chapagain, Rakesh Verma}

Department of Clinical Pharmacology and Therapeutics, B. P. Koirala Institute of Health Sciences, Dharan, Nepal

\author{
Received: 10 October 2020 \\ Revised: 09 November 2020 \\ Accepted: 10 November 2020 \\ *Correspondence: \\ Dr. Utshav Chapagain, \\ Email: utshavchapagain08@gmail.com
}

Copyright: () the author(s), publisher and licensee Medip Academy. This is an open-access article distributed under the terms of the Creative Commons Attribution Non-Commercial License, which permits unrestricted non-commercial use, distribution, and reproduction in any medium, provided the original work is properly cited.

\begin{abstract}
Currently, novel coronavirus disease 2019 (COVID-19) is a big threat to global health which has revived the potential beneficial effect of ancient convalescent plasma therapy (CPT). This review was conducted to evaluate the effectiveness and adverse drug reactions associated with convalescent plasma therapy in COVID-19 patients, based on articles available to date. PubMed, Google Scholar, Cochrane library, and Hinari databases were searched until 15th September 2020. Every country across the globe today is encountered with a virus that has impacted millions of lives today and for generations to come. Nonetheless recommended antiviral drugs and vaccines are not evident and specified for novel coronavirus disease. This is now very well known that scientists and medical experts across the world are vigilant about recommending the use of CPT and call it an investigational treatment that may help in assisting recovery. The World health organization has perpetuated that there is not enough proof that plasma therapy works in treating those fighting the novel coronavirus. Therefore, convalescent plasma therapy is a feasible and immediate option for alleviating the impact of the disease. Comparing the effectiveness of convalescent plasma therapy with SARS-CoV, MERS-CoV, and COVID-19 would help in deriving proper outcomes for COVID-19 infected cases.
\end{abstract}

Keywords: Antibodies, COVID-19, Convalescent plasma therapy, SARS-CoV-2

\section{INTRODUCTION}

Since December 2019, an outbreak of severe acute respiratory syndrome coronavirus 2 (SARS-CoV-2) infection named, coronavirus disease 2019 (COVID-19) by the World health organization (WHO) has spread rapidly around the world, with high rates of transmission and considerable mortality. Its symptoms range from mild, self-limited respiratory disease to severe progressive pneumonia, multiple organ failure, and even death. ${ }^{1,2}$ As of 15 September 2020, the World Health Organization has reported 29,730,066 confirmed cases of COVID-9, with 939,192 deaths worldwide. ${ }^{3}$ The severity and epidemic potential of COVID-19 has paralyzed the world's health care system and threatened economic stability. Unfortunately, to date, apart from symptomatic treatment and supportive care, there is no effective treatment or vaccine available to cure the disease. ${ }^{4}$

Convalescent plasma is obtained from the blood of a recovered patient. Plasma is the protein-rich component of blood, and the word convalescence comes from Latin words for "together" and "to grow strong". 5 A patient has "convalesced" when they recover from an infection. ${ }^{5}$ In the 1890s, passive immunization therapy was used successfully to treat individuals with infectious diseases. Such individuals after recovery have particular microorganisms neutralizing antibodies when blood samples are drawn and screened. Following the identification of individuals with high titers of neutralizing antibody, convalescent plasma could be administered in individuals with specified clinical disease 
to reduce symptoms and mortality. Therefore, convalescent plasma therapy (CPT) has been one of the centres of attraction and burning topic in the global pandemic. $^{6}$

The United States food and drug administration (US FDA) has suggested that administration and study of investigational convalescent plasma therapy may provide therapeutic benefit for the treatment of COVID-19. Although the use of convalescent plasma shows promise, the evidence supporting its use in the treatment of COVID-19 remains limited as the interim resort and thus needs further investigation.

The purpose of this review was to evaluate true efficacy and adverse drug reactions associated with the administration of convalescent plasma therapy.

\section{HISTORY OF CONVALESCENT PLASMA THERAPY FOR INFECTIOUS DISEASES}

Before the antibiotic era, infectious diseases like scarlet fever and pneumococcal pneumonia were treated using serum (plasma minus clotting factors) therapy. In 1890, blood serum was collected from immunized animals and was used to treat diphtheria and tetanus. ${ }^{8}$

Table 1: Classical uses of antibody therapy against infectious diseases from ancient to modern period.

\begin{tabular}{|c|c|}
\hline Period & Infectious diseases \\
\hline 1890 A.D. & $\begin{array}{ll}\text { - } & \text { Diptheria } \\
\text { - } & \text { Tetanus }\end{array}$ \\
\hline 1900 A.D. & $\begin{array}{ll}\text { - } & \text { Meningococcal infection } \\
\text { - } & \text { Rheumatic Fever }\end{array}$ \\
\hline 1910 A.D. & $\begin{array}{ll}\text { - } & \text { Mumps } \\
\text { - } & \text { Measles }\end{array}$ \\
\hline 1917 A.D. & - $\quad$ Scarlet fever \\
\hline 1918 A.D. & - $\quad$ Spanish Flu \\
\hline 1920 A.D. & $\begin{array}{l}\text { - } \quad \text { Pneumococcal Pneumonia } \\
\text { - } \quad \text { Chickenpox }\end{array}$ \\
\hline 1930 A.D. & - Anthrax \\
\hline 1940 A.D. & - Tularemia \\
\hline 1950 A.D. & - $\quad$ Rabies \\
\hline 1976 A.D. & - $\quad$ Ebola \\
\hline 1979 A.D. & - Argentine Hemorrhagic Fever \\
\hline 2003 A.D. & $\begin{array}{ll}\text { - } & \text { SARS-CoV } \\
\text { - } & \text { Avian Flu (H5N1) } \\
\end{array}$ \\
\hline 2009 A.D. & - $\quad$ Swine Flu (H1N1) \\
\hline 2012 A.D. & - $\quad$ MERS-CoV \\
\hline 2013 A.D. & - Ebola \\
\hline 2019 A.D. & - $\quad$ COVID-19 \\
\hline
\end{tabular}

There are numerous examples throughout history where convalescent serum was used to treat various diseases, like rheumatic fever, scarlet fever, mumps, measles, chickenpox, and meningococcal infections (Table 1). ${ }^{8-13}$ Between 1918 to 1920 , convalescent serum was used in the treatment of the Spanish Flu pandemic where a metaanalysis study showed a significant reduction in mortality risk in patients treated with convalescent serum. ${ }^{14,15}$

Later in the mid-20th century, after the arrival of antimicrobials agents, the use of convalescent plasma therapy had been reduced. Yet whenever new epidemics or pandemics emerged, the interest in convalescent plasma therapy is renewed.

In 1979, convalescent plasma was used to treat patients with Argentine hemorrhagic fever virus and a lower mortality rate was seen in patients receiving convalescent plasma when compared to patients receiving normal plasma. ${ }^{16}$ Similar outcomes were reported for successive epidemics of the disease. ${ }^{16}$

Since, past two decades, CPT was successfully used in the treatment of SARS in 2003, MERS in 2012, and H1N1 swine influenza pandemic (2009) with satisfactory efficacy and safety as well as during the Ebola virus outbreak in West Africa in 2013. ${ }^{17-20}$ Due to the similarity in virological and clinical characteristics among SARS, MERS, and COVID-19, CPT might be a promising treatment option for COVID-19 rescue. ${ }^{21,22}$

\section{USE OF PLASMA THERAPY FOR SARS}

Cheng et al conducted a study to evaluate the efficacy of convalescent plasma therapy in patients with severe acute respiratory syndrome (SARS). ${ }^{17}$ Eighty SARS patients were given convalescent plasma, between 20 March and 26 May 2003 at Prince of Wales Hospital, Hong Kong.

Patients with suspected SARS were given cefotaxime and levofloxacin (or clarithromycin) on the day of admission. ${ }^{17}$ If fever persisted, ribavirin and prednisolone were started on day 3. Patients with radiographic progression and hypoxemia were given pulsed methylprednisolone. ${ }^{17}$ Patients whose condition continued to deteriorate, $\mathrm{SaO} 2<90 \%$ on $0.5 \mathrm{FiO} 2$, were given 200-400 $\mathrm{ml}$ of $\mathrm{ABO}$ compatible convalescent plasma at the discretion of the attending clinicians and according to convalescent plasma availability. A higher day 22 discharge rate was observed in patients who were given convalescent plasma before day 14 of illness (58.3\% vs $15.6 \%$; $\mathrm{P}<0.001)$ and among those who were PCR positive and seronegative for coronavirus at the time of plasma infusion $(66.7 \%$ vs $20 \%$; $\mathrm{P}=0.001)$. There were no immediate adverse effects following plasma infusion.

The data suggests that it was not a randomized trial where recipients of convalescent plasma therapy were at the discretion of the attending physicians and according to plasma availability. Non-standardized amount of antibody might have contributed to the variations in clinical outcomes. A potential risk of transfusiontransmitted infection was present. No placebo group for comparison was evident during the trial. 
Henceforth, it may be worthwhile for future researchers to test the effectiveness of therapy with convalescent plasma or SARS-specific hyperimmune globulin in patients in the early phase of SARS during the next outbreak. The randomized control trial with a placebo group should be conducted for comparison and to illustrate the effectiveness of CP in patients with SARS.

\section{USE OF PLASMA THERAPY FOR MERS}

The coronavirus outbreak of SARS-CoV was followed by the MERS-CoV outbreak which occurred in 2012. It caused severe infection in the respiratory tract of infected persons in Saudi Arabia and other Middle East countries. $^{23}$

In vitro study showed cross-reactive antibodies in convalescent SARS patients sera, which act against other beta-coronavirus including MERS-CoV.$^{24}$ Out of 28 sera, 7 had anti-MERS-CoV neutralizing antibodies at low titers. $^{24}$

Convalescent sera were recommended in a study by the International severe acute respiratory and emerging infection consortium (ISARIC). ${ }^{25}$ Since there is a lack of high-quality clinical evidence, protocols must be developed to use it in randomized-controlled trials to determine the most effective therapy for this MERS-CoV.

\section{USE OF PLASMA THERAPY FOR COVID-19}

Currently, convalescent plasma with neutralizing antibodies is being explored as it can be used for investigational purposes in the COVID-19 pandemic. It is multifaceted inapplicability as it can be used for prophylaxis or treatment as illustrated in (Figure 1).

In case of prophylaxis, an individual at high risk of infection (due to age or underlying medical conditions or those likely to be in contact with a confirmed case of COVID-19) could be administered convalescent plasma for protection against infection. Alternatively, it can be administered to treat individuals who have contracted the infection but have not made sufficient antibodies to augment their immune response, improve disease course, and enhance recovery. ${ }^{26}$

Shen et al published the first preliminary case series of convalescent plasma therapy against COVID-19 in about 5 critically ill patients with COVID-19 who were treated using plasma from recovered individuals. ${ }^{27}$

All 5 patients had severe acute respiratory distress syndrome and were receiving mechanical ventilation. 2 had bacterial pneumonia and 1 needed extracorporeal membrane oxygenation (ECMO). Plasma was transfused to four patients without coexisting diseases around hospital day 20 and in a patient with hypertension and mitral valve insufficiency, was transfused at day $10 .^{28}$ These patients also received antiviral treatment with lopinavir/ ritonavir and interferon. ${ }^{28}$ The use of convalescent plasma may have contributed to their recovery as clinical status of all patients had improved just about 1 week after transfusion, as indicated by normalization of body temperature, improvements in sequential organ failure assessment (SOFA) scores, and PAO2/FIO2 ratio.28 Also, the patients' neutralizing antibody titers increased and respiratory samples tested negative for SARS-CoV-2 between 1 and 12 days after transfusion. ${ }^{28}$

These data suggest that intervention, administration of convalescent plasma was not evaluated in a randomized clinical trial. The outcomes in the treatment group were not compared with a control group who did not receive the intervention. Hence, it is not possible to determine the true clinical effect of this intervention. It is also unclear whether the timing of administration of convalescent plasma is optimal or if earlier administration might have different clinical outcomes.

Despite these limitations, the study provides some evidence to support the possibility of evaluating plasma therapy in patients with COVID-19. Henceforth, future researchers should focus on conducting a randomized clinical trial for convalescent plasma therapy against COVID-19 where outcomes in the treatment group could be compared with the control group. These trials should be performed with early administration of convalescent plasma along with other clinical interventions as a treatment group and only clinical intervention as a control group to determine the true efficacy of ongoing trials.

Li et al conducted the first randomized clinical trial of convalescent plasma therapy against COVID-19. In the primary analysis, 52 patients were randomized to receive convalescent plasma along with standard treatment (intervention) and 51 patients to receive standard treatment alone (control). ${ }^{29}$

The primary outcome (time to clinical improvement within 28 days) was 2.15 days shorter (95\% CI, -5.28 to 0.99 days) in the intervention arm compared to control arm. Similarly, clinical improvement at 28 days occurred in 27 patients $(51.9 \%)$ in the intervention arm vs 22 patients $(43.1 \%)$ in the control arm (difference, 8.8\%; $95 \% \mathrm{CI},-10.4 \%$ to $28 \%$; hazard ratio, 1.40 [95\% CI, $0.79-2.49] ; \mathrm{P}=0.26){ }^{30}$

In patients with severe disease (23 in the intervention group and 22 in the control group), time to clinical improvement within 28 days was 4.94 days shorter $(95 \%$ CI, -9.33 to -0.54 days) in the intervention arm compared with the control arm, and clinical improvement at 28 days occurred in 21 patients $(91.3 \%)$ in the intervention arm vs 15 patients $(68.2 \%)$ in the control arm (hazard ratio, 2.15 [95\% CI, 1.07-4.32]; $\mathrm{P}=0.03) .{ }^{30}$ In patients with the lifethreatening disease (29 in the intervention arm and 29 in the control arm), there were no significant differences in the primary outcome. Following plasma transfusion, two patients experienced adverse events which improved with supportive care. ${ }^{30}$ 


\section{Prophylaxis}

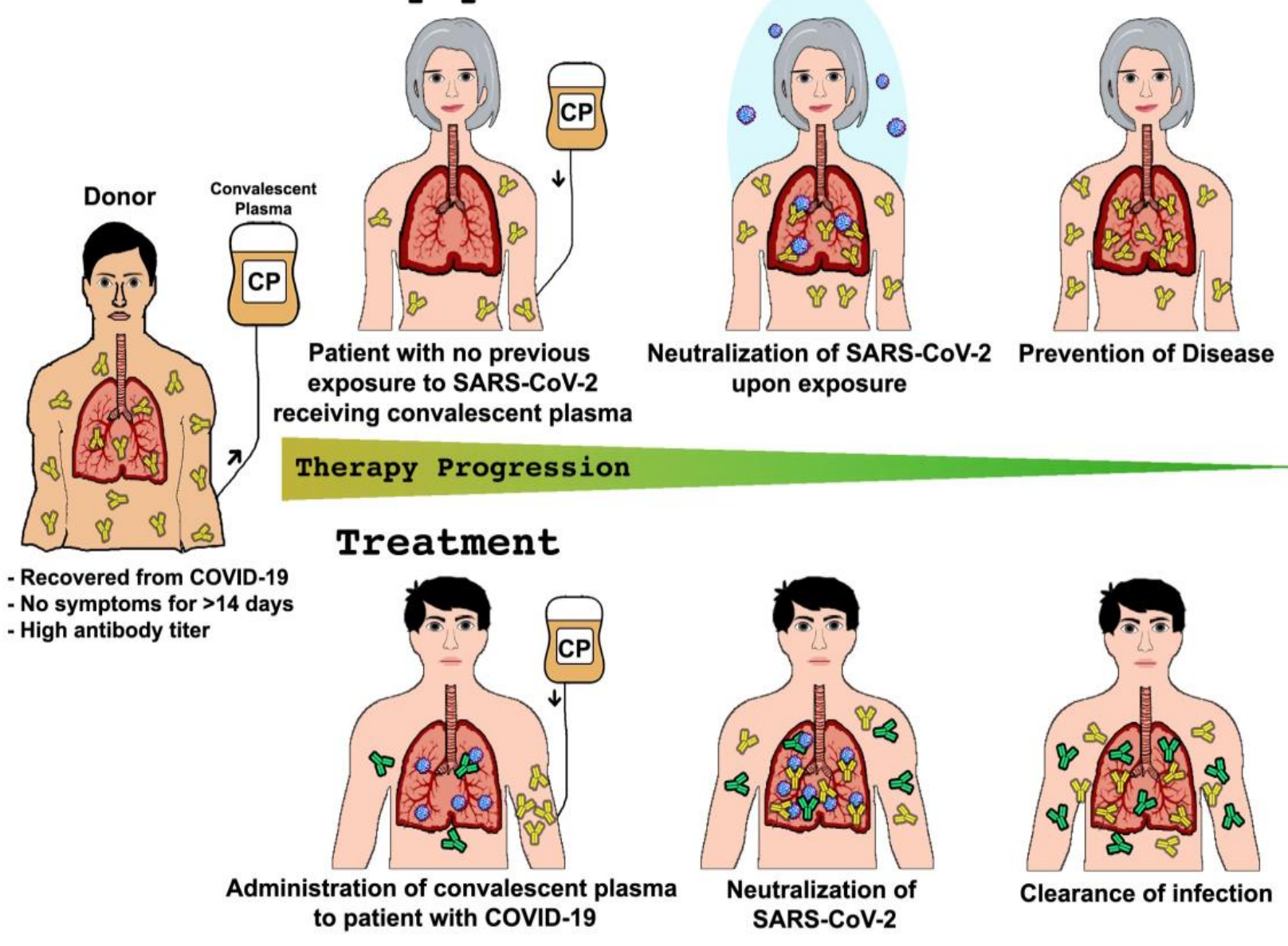

Figure 1: Overview of the use and applications of CP therapy. ${ }^{16}$

Virus-neutralizing antibodies in the plasma of a patient who recovered from COVID-19 can be administered prophylactically to prevent infection in vulnerable individuals and those with known exposure to the virus (Prophylaxis). ${ }^{16}$ Convalescent plasma can also be administered to infected individuals to improve the clinical outcome (Treatment). ${ }^{16} \mathrm{CP}$, convalescent plasma; COVID-19, coronavirus disease 2019; SARS-CoV-2, severe acute respiratory syndrome coronavirus 2.

Table 2: Characteristics of the studies on convalescent plasma therapy

\begin{tabular}{|c|c|c|c|c|c|c|}
\hline $\begin{array}{l}\text { Author } \\
\& \\
\text { reference }\end{array}$ & Study type & Regimen & $\begin{array}{l}\text { \# Patients } \\
\text { With } \\
\text { Indications }\end{array}$ & $\begin{array}{l}\text { Time of } \\
\text { administratio } \\
\mathrm{n} \text { of } \mathbf{C P}\end{array}$ & \multicolumn{2}{|c|}{ Outcome and adverse effect } \\
\hline $\begin{array}{l}\text { Cheng } \\
\text { et al. }{ }^{17}\end{array}$ & Cohort & $\begin{array}{l}200-400 \mathrm{ml} \\
(4-5 \mathrm{ml} / \mathrm{kg}) \\
\text { of ABO } \\
\text { compatible } \\
\text { CP }\end{array}$ & $\begin{array}{l}80 \text { patients } \\
\text { (SARS) }\end{array}$ & $\begin{array}{l}\text { On day } 14 \text { of } \\
\text { starting } \\
\text { symptoms }\end{array}$ & \multicolumn{2}{|c|}{$\begin{array}{l}\text { Overall, the mortality rate was } 12.5 \% \\
\text { compared to } 17 \% \text { of SARS patient. No } \\
\text { immediate adverse effects were observed }\end{array}$} \\
\hline $\begin{array}{l}\text { Shen } \\
\text { et al. }{ }^{27}\end{array}$ & Case series & $\begin{array}{l}\text { Two } \\
\text { consecutive } \\
\text { transfusions } \\
\text { of } 200-250 \mathrm{ml} \\
\text { ( } 400 \mathrm{ml} \text { net.) } \\
\text { of ABO } \\
\text { compatible } \\
\text { CP }\end{array}$ & $\begin{array}{l}\text { Five } \\
\text { critically ill } \\
\text { patients with } \\
\text { laboratory } \\
\text { confirmed } \\
\text { COVID-19 } \\
\text { and ARDS } \\
\text { (SARS- } \\
\text { CoV-2) }\end{array}$ & $\begin{array}{l}\text { Between } 10-22 \\
\text { days after } \\
\text { admission }\end{array}$ & \multicolumn{2}{|c|}{$\begin{array}{l}\text { Three patients were discharged (length of } \\
\text { hospital stay: } 53,51 \text {, and } 55 \text { days), and } \\
\text { Two were in stable condition at } 37 \text { days } \\
\text { after transfusion. }\end{array}$} \\
\hline $\begin{array}{l}\mathrm{Li} \\
\text { et al. }{ }^{29}\end{array}$ & $\begin{array}{l}\text { Open-label, } \\
\text { Multicenter } \\
\text { Randomize }\end{array}$ & $\begin{array}{l}\text { Approximatel } \\
\text { y } 4-13 \mathrm{ml} / \mathrm{kg} \\
\text { of recipient }\end{array}$ & $\begin{array}{l}103 \text { patients } \\
\text { with severe } \\
\text { or life- }\end{array}$ & $\begin{array}{l}14 \text { days after } \\
\text { onset of } \\
\text { symptoms in }\end{array}$ & $\begin{array}{l}\text { CP } \\
\text { Group } \\
(\mathrm{n}=52)\end{array}$ & $\begin{array}{l}\text { Control P value } \\
\text { Group } \\
(\mathrm{n}=52)\end{array}$ \\
\hline
\end{tabular}




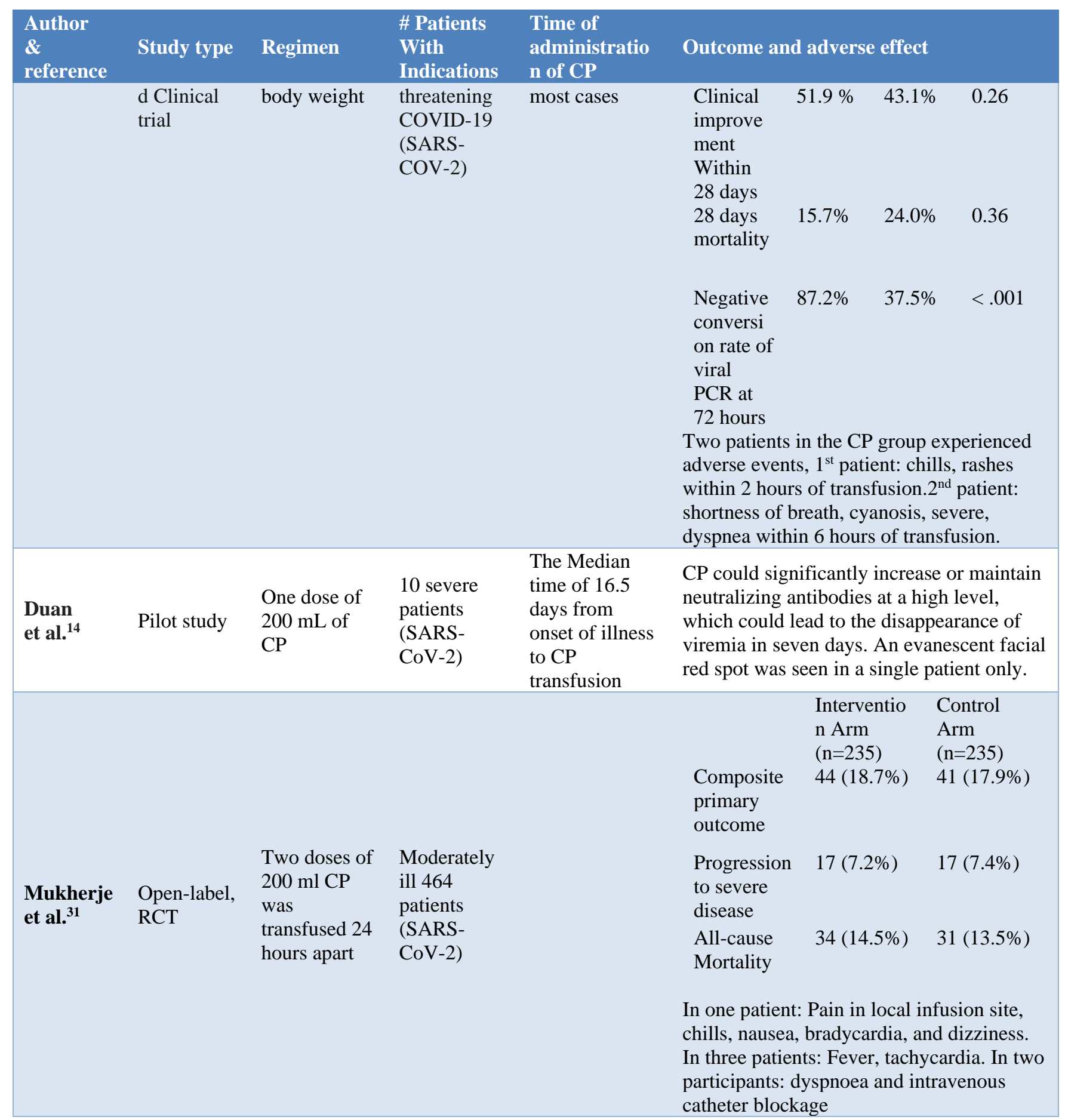

CP: Convalescent plasma, SARS: Severe acute respiratory syndrome, SARS-CoV-2: Severe acute respiratory syndrome coronavirus 2, COVID-19: Coronavirus disease 2019, ARDS: Acute respiratory distress syndrome.

These data suggest that it was an open-label study with a smaller sample size as well as the early termination of the study. The study was underpowered to detect a clinically important benefit of convalescent plasma therapy. ${ }^{29}$ It is unclear whether earlier treatment would have resulted in greater benefit. ${ }^{29}$ No specific protocol was mentioned for using standard therapy in both groups which could have potentially influenced outcomes. Plasma was not used for the control group which would have been more ideal in making blinded design possible. ${ }^{29}$
To sum it up, this study used a randomized trial design and well-characterized plasma units with a high titer of antibody to SARS-CoV-2. The study findings should be analyzed cautiously since standard treatment and supportive care may vary from hospital to hospital across the globe. Future researchers should focus on conducting a close level study with a greater sample size and plasma as a control group. Specified protocol for standard therapy as well as early treatment with convalescent plasma therapy could influence outcomes. 
Duan et al conducted a pilot study in three hospitals to explore the feasibility of convalescent plasma therapy in a group of 10 patients with severe disease.

All patients received antiviral agents, other supportive care, and $200 \mathrm{ml}$ of convalescent plasma with high neutralizing antibody titers. The primary and secondary endpoints were the safety of convalescent plasma transfusion and improvement of clinical symptoms and laboratory parameters within 3 days of convalescent plasma transfusion respectively. The median time from the start of symptoms to $\mathrm{CP}$ transfusion was 16.5 days. $\mathrm{CP}$ was well tolerated and could increase or maintain neutralizing antibodies at high levels, leading to the disappearance of viremia in 7 days and improved clinical symptoms in all patients within one to three days of administration. ${ }^{14}$ There were no severe adverse events after convalescent plasma transfusion.

This study suggests that the patients also received other standard care. All patients received antiviral treatment and these antiviral agents could contribute to the recovery of patients, or synergize with the therapeutic effect of $\mathrm{CP}$ which could not be ruled out. Some patients also received glucocorticoid therapy, which might interfere with immune response and delay virus clearance.

Although the kinetics of viremia during natural history remains unclear, the relationship between SARS-CoV-2 RNA reduction, CP therapy, the optimal concentration of neutralizing antibodies, and treatment schedule, should have been further clarified. Dynamic changes of cytokines during treatment were not investigated. ${ }^{14}$

Despite various limitations, the study provides evidence that convalescent plasma therapy shows a potential therapeutic effect and low risk in the treatment of severe COVID-19 patients. The optimal dose and treatment time point and definite clinical benefits of convalescent plasma therapy owing to dynamic changes of cytokines can be further investigated in randomized clinical studies.

Mukherjee et al conducted an open-label, parallel-arm, phase II, multicentric randomized controlled trial in 464 hospitalized, moderately ill confirmed COVID-19 patients $(\mathrm{PaO} 2 / \mathrm{FiO} 2: 200-300$ or respiratory rate $>24 / \mathrm{min}$ and $\mathrm{SpO} 2 \leq 93 \%$ on room air) in 39 tertiary care hospitals across India. ${ }^{31}$

A total of 235 patients were randomized to receive Convalescent Plasma with the best standard of care (BSC) (intervention group) and 229 patients received BSC alone (control group). Patients in the intervention arm received two doses of $200 \mathrm{ml}$ of CP, 24 hours apart. Thirty-four patients $(14.5 \%)$ in the intervention arm and $31(13.5 \%)$ in the control arm died (adjusted odds ratio (aOR) was 1.06 [95\% CI: 0.61 to 1.83$]$ ). In both arm 17 patients progressed to severe disease (7.2\% vs. $7.4 \%$; aOR: $1.04 ; 95 \% \mathrm{CI}: 0.51$ to 2.11 ). The Composite primary outcome was achieved in 44 (18.7\%) and 41
(17.9\%) patients in the intervention group and the control group respectively. ${ }^{31}$

In moderately ill, hospitalized COVID-19 patients the convalescent plasma therapy did not reduce 28-day mortality or progression to severe disease. ${ }^{31}$ On days three and five, there was a reduction in supplemental oxygen requirement. On day seven, there was a resolution of shortness of breath and fatigue. Convalescent plasma therapy was associated with the early negative conversion of SARS-CoV-2 viral RNA. Convalescent plasma therapy as an effective treatment modality for moderately ill COVID-19 patients is limited. These data suggest that it was an open-label study with anchoring bias to the clinician with no initial measurement of neutralizing antibodies titers in donors and participants. Since more patients with shortness of breath and fatigue were enrolled in the intervention group compared to the control group, it is unclear to justify the similarities in the result of the two groups.

Future researchers should focus on minimizing any type of bias associated with randomized control trial and prior measurement of neutralizing antibody titers in donors and participants may further clarify the role of $\mathrm{CP}$ in the management of COVID-19.

\section{CONCLUSION}

The aforementioned studies suggest that the greatest global health crisis caused by the COVID-19 outbreak needs to be controlled. Convalescent Plasma therapy for SARS-CoV-2 and other viruses have shown promising results. While evaluating existing drugs and developing new specific vaccines, convalescent plasma therapy has the potential to provide an effective therapeutic option with promising evidence on safety, improvement of clinical symptoms, and reduction of mortality rate in severe or life-threatening COVID-19 infected cases. Further studies are needed to optimize patient selection by enrolling a greater sample size for moderate to severely infected cases of COVID-19. Early administration of convalescent plasma during the trial will prove to evaluate its beneficial effect and true efficacy. Specific protocol for standard therapy and supportive care should be simplified as guidelines at health institutions across the globe. Research is still being worked on regarding the effectiveness of convalescent plasma for treating COVID19.

\section{Funding: No funding sources \\ Conflict of interest: None declared \\ Ethical approval: Not required}

\section{REFERENCES}

1. Wang D, Hu B, Hu C, Zhu F, Liu X, Zhang J, et al. Clinical characteristics of 138 hospitalized patients with 2019 novel coronavirus-infected pneumonia in 
Wuhan, China. J Am Med Assoc. 2020;323(11):1061-9.

2. Wu Z, McGoogan JM. Characteristics of and important lessons from the coronavirus disease 2019 (COVID-19) outbreak in China: summary of a report of 72314 cases from the Chinese Center for Disease Control and Prevention. J Am Med Assoc. 2020;323(13):1239-42.

3. World Health Organization. Coronavirus disease 2019 (COVID-19) -Situation Report - 90 (September 15, 2020). Available at: https://www.who.int/emergencies/diseases/novelcoronavirus-2019/situation-reports. Accessed on 15 September 2020.

4. Cascella M, Rajnik M, Cuomo A, Dulebohn SC, Di Napoli R. Features, Evaluation and Treatment Coronavirus (COVID-19) [Updated 2020 Mar 8]. In: StatPearls. Treasure Island (FL): Stat Pearls Publishing. 2020.

5. Jonathan Forani. CORONAVIRUS. Available at: https://www.ctvnews.ca/health/coronavirus/what-isconvalescent-plasma-1.5076738. Accessed on 24 August 2020.

6. Casadevall A, Pirofski LA. The convalescent sera option for containing COVID-19. J Clin Invest. 2020;130(4):1545-8.

7. Center for Biologics Evaluation and Research. Investigational COVID-19 convalescent plasma Emergency INDs 26 March 2020. Available at: https://www.fda.gov/vaccines-blood-

biologics/investigational-new-drug-ind-or-deviceexemptionide-process-cber/investigational-covid-19convalescent-plasma-emergency-inds. Accessed on 20 September 2020.

8. Behring Ev. Ueber das Zustandekommen der Diphtherie-Immunität und der Tetanus-Immunität bei Thieren. 2013.

9. Moore JJ. The Action of Vaccines and of Concentrated Antistreptococcus Serum in Experimental Streptococcal Arthritis. J Infect Dis. 1914;15(1):215-26.

10. Smith DD. Serum treatment of scarlet fever [doctoral thesis]. Omaha (Nebraska): University of Nebraska; 1934.

11. Lewis JM, Barenberg LH. The use of convalescent serum in the treatment of measles, chickenpox, mumps and whooping cough, including the prophylactic value of parental blood. State J Med. 1933;33:2.

12. Kohn JL, Klein IF, Schwarz H. Treatment of pre eruptive measles with convalescent serum. J Am Med Assoc. 1938;111(26):2361-4.

13. Casadevall A, Scharff MD. Serum therapy revisited: animal models of infection and development of passive antibody therapy. Antimicrobial Agents and Chemotherapy. 1994;38(8):1695-702.

14. Duan K, Liu B, Li C, Zhang H, Yu T, Qu J, et al. Effectiveness of convalescent plasma therapy in severe COVID-19 patients. Proc Natl Acad Sci U S A. $2020 ; 117(17): 9490-6$.
15. Joyner MJ, Wright RS, Fairweather D, Senefeld JW, Bruno KA, Klassen SA, et al. Early safety indicators of COVID-19 convalescent plasma in 5000 patients. J Clin Invest. 2020;130(9):4791-7.

16. Montelongo-Jauregui D, Vila T, Sultan AS, JabraRizk. Convalescent serum therapy for COVID-19: A 19 th century remedy for a 21 st century disease. PLoS Pathog. 2020;16(8):e1008735.

17. Cheng Y, Wong R, Soo YO, Wong WS, Lee CK, Ng $\mathrm{MH}$, et al. Use of convalescent plasma therapy in SARS patients in Hong Kong. Eur J Clin Microbiol Infect Dis. 2005;24(1):44-6.

18. Zhou B, Zhong N, Guan Y. Treatment with convalescent plasma for influenza A (H5N1) infection. N Engl J Med. 2007;357(14):1450-1.

19. Hung IF, To KK, Lee CK, Lee KL, Chan K, Yan $\mathrm{WW}$, et al. Convalescent plasma treatment reduced mortality in patients with severe pandemic influenza A (H1N1) 2009 virus infection. Clin Infect Dis. 2011;52(4):447-56.

20. Ko JH, Seok H, Cho SY, Ha YE, Baek JY, Kim SH, et al. Challenges of convalescent plasma infusion therapy in Middle East respiratory coronavirus infection: a single centre experience. Antivir Ther. 2018;23(7):617-22.

21. Lee PI, Hsueh PR. Emerging threats from zoonotic coronaviruses-from SARS and MERS to 2019-nCoV. J Microbiol Immunol Infect. 2020;53(3):365-7.

22. Chen L, Xiong J, Bao L, Shi Y. Convalescent plasma as a potential therapy for COVID-19. Lancet Infect Dis. 2020;20(4):398-400.

23. Zaki AM, Van Boheemen S, Bestebroer TM, Osterhaus AD, Fouchier RA. Isolation of a novel coronavirus from a man with pneumonia in Saudi Arabia. N Engl J Med. 2013;369(4):394.

24. Chan KH, Chan JF, Tse H, Chen H, Lau CC, Cai JP, et al. Cross-reactive antibodies in convalescent SARS patients' sera against the emerging novel human coronavirus EMC (2012) by both immunofluorescent and neutralizing antibody tests. $\mathbf{J}$ Infect. 2013;67(2):130-40.

25. ISARIC, International Severe Acute Respiratory \& Emerging Infection Consor-tium. Clinical Decision Making Tool for Treatment of MERS-CoV v.1.0, 18 June, 2013. Available at: http://www.hpa.org.uk/webc/HPAwebFile/HPAweb_ C/ 1317139281416. Accessed on 26 July 2020.

26. Bloch EM, Shoham S, Casadevall A, Sachais BS, Shaz B, Winters JL, et al. Deployment of convalescent plasma for the prevention and treatment of COVID-19. J Clin Invest. 2020;130(6):2757-65.

27. Shen C, Wang Z, Zhao F, Yang Y, Li J, Yang J, et al. Treatment of 5 critically ill patients with COVID-19 with convalescent plasma. J Am Med Assoc. 2020;323(16):1582-9.

28. Roback JD, Guarner J. Convalescent Plasma to Treat COVID-19: Possibilities and Challenges. J Am Med Assoc. 2020;323(16):1561-2.

29. Li L, Zhang W, Hu Y, Tong X, Zheng S, Yang J, et al. Effect of Convalescent Plasma Therapy on Time 
to Clinical Improvement in Patients with Severe and Life-threatening COVID-19: A Randomized Clinical Trial. J Am Med Assoc. 2020;324(5):460-70.

30. Casadevall A, Joyner MJ, Pirofski L. A Randomized Trial of Convalescent Plasma for COVID-19Potentially Hopeful Signals. J Am Med Assoc. 2020;324(5):455-7.

31. Agarwal A, Mukherjee A, Kumar G, Chatterjee P, Bhatnagar T, Malhotra P. Convalescent plasma in the management of moderate covid-19 in adults in India: open label phase II multicentre randomised controlled trial (PLACID Trial). Bio Med J. 2020:371.

Cite this article as: Chapagain U, Rauniar GP, Chapagain K, Verma R. Convalescent plasma therapy for COVID-19: a review of old therapy against new disease. Int J Basic Clin Pharmacol 2020;9:1909-16. 